\title{
The Relationships among Human Resource Management Practices, Organizational Commitment, and Knowledge Management Processes: A Structural Equation Modeling Approach
}

\author{
Bader Yousef Obeidat ${ }^{1}$, Ra'ed (Moh'd Taisir) Masa'deh² \& Ayman Bahjat Abdallah ${ }^{3}$ \\ ${ }^{1}$ Business Administration Department, Faculty of Business, The University of Jordan, Jordan \\ ${ }^{2}$ Management Information Systems Department, Faculty of Business, The University of Jordan, Jordan \\ ${ }^{3}$ Department of Business Administration, Faculty of Economics and Administrative Sciences, Applied Science \\ University, Jordan \\ Correspondence: Bader Yousef Obeidat, Business Administration Department, Faculty of Business, The \\ University of Jordan, Jordan. E-mail: b.obeidat@ju.edu.jo
}

Received: December 14, 2013

Accepted: January 13, $2014 \quad$ Online Published: February 21, 2014

doi:10.5539/ijbm.v9n3p9

URL: http://dx.doi.org/10.5539/ijbm.v9n3p9

\begin{abstract}
Human resources and knowledge management are considered to be one of the most important factors within organizations that help them to achieve a competitive advantage. However, organizations should take care of the human factor and increase their commitment within organizations to take advantage of the knowledge within them. The purpose of this research is to investigate the relationship between human resources management practices and organizational commitment, on the one hand, and their relationship with knowledge management process, on the other hand.

Consultancy firms operating in Jordan were used as the main sample of this study. A random sample was selected where 220 questionnaires were distributed to such firms. Only 207 questionnaires were submitted back with a response rate of $52 \%$. A theoretical model was proposed and tested using structural equation modeling (SEM). The results of the SEM analysis indicated that human resources practices (recruitment methods, training and development, performance appraisals, and reward systems) have a significant influence on organizational commitment (affective commitment, continuance commitment, and normative commitment). Finally, the study did not find a direct relationship between human resource (HR) practices and knowledge management (KM) processes (knowledge acquisition, knowledge distribution, knowledge interpretation, and organizational memory). However, causal links were founded between human resource practices and organizational commitment, on the one hand, and organizational commitment and knowledge management processes, on the other hand.
\end{abstract}

Keywords: human resource, organizational commitment, knowledge management, SEM analysis

\section{Introduction}

Organizations operate in an environment characterized by uncertainty, instability and change that provoke the appearance of various challenges (Bimpitsos \& Petridou, 2012). Such environment includes many factors as increased globalization, rapid technological change, and the growing need for qualified employees and improved performance (Vanhala \& Stavrou, 2013). This forces organizations to try and exploit the resources at its disposal in order to achieve a competitive advantage (Savaneviciene \& Stakeviciute, 2011). Human resources are considered critical factors contributing to an organization's success (Dominguez, 2011). According to Othman (2009) using human resources in a strategic manner is required to overcome the different challenges organizations face. Therefore, effectively managing these resources is of importance to all organization (Juhdi et al., 2011). Managing the human resources of an organization requires the use of different practices (Ortega-Parra \& Sastre-Castillo, 2013) that play a significant role in helping organizations create and sustain the performance they desire (Fong et al., 2011) as they influence the attitudes and behaviours of employees (Lew, 2011).

In addition, organizations seek to develop a committed workforce (Yew, 2013) and finding the best way to retain their employees (Riveros \& Tsai, 2011). According to Tiwari \& Saxena (2012), an organization's behaviour can 
be improved in such areas as staff commitment, competency, and flexibility by managing the human resources available in that organization. More specifically, it is reported that several human resource management (HRM) practices can affect employee commitment and motivation these include recruitment and selection, training and development, performance appraisal, teamwork, and compensation and reward (Fong et al., 2011). Furthermore, given that the twenty-first century is labelled as the century of knowledge (Jelenic, 2011), it is clear that successful organizations are those that are able to improve and develop their knowledge (Akhavan et al., 2013). Because knowledge is a valuable asset (Pinho et al., 2012) which should be managed effectively to help organizations achieve higher organizational innovation which in turn leads to achieving competitive advantage (Tan \& Nasurdin, 2011). In a world that is moving toward a knowledge-based economy human resources are becoming increasingly important (Ubeda-Garcia, 2013). According to Fong et al. (2011), knowledge resides in the minds of employees but that knowledge can be easily lost if employees decide to leave the organization. Due to that reason organizations seek to improve the knowledge management (KM) processes of acquisition, distribution, interpretation, and organizational memory (Jimenez-Jimenez \& Sanz-Valle, 2013).

The purpose of this research is to investigate the relationship between human resources management practices and organizational commitment on the one hand and their relationship with knowledge management process, on the other hand. To achieve this purpose, the first sections discuss the theoretical background, research methodology, research model, and hypotheses. Data analysis, discussion results and conclusions, limitations and future work will be discussed in the final sections.

\section{Theoretical Background}

Many studies discussed the relationship between human resource management and knowledge management process (see for example Hislop, 2003; Oltra, 2005; Chiang et al., 2011; Fong et al., 2011; Jimenez-Jimenez \& Sanz-Valle, 2013). Other studies discussed the relationship between human resource management and organizational commitment (see for example Edgar \& Geare, 2005; Sanders et al., 2008; Juhdi et al., 2011; Zaitouni et al., 2011; Imran \& Ahmed, 2012). Whereas, (Malhotra \& Galletta, 2003; Alvesson, 2005; Thompson \& Heron, 2005; Rocha et al., 2008; Chiang et al., 2011; Neyestani et al., 2013) investigated the relationship between organizational commitment and knowledge management process. This section discussed the previous literature related to the subject of this study.

\subsection{Human Resources Management (HRM) Practices}

Employees as human resources are considered to be one of the most important resources within an organization that help in achieving a competitive advantage (Wheelen \& Hunger, 2013). However, it is argued that managing human resources is more difficult than managing technology or capital (Tiwari \& Saxena, 2012). Human resources management (HRM) is defined as all decisions and practices that affect employees within organizations (Shahnawaz \& Juyal, 2006). HRM practices are defined as "organizational activities directed at managing the pool of human resources and ensuring that the resources are employed towards the fulfilment of organizational goals" (Tiwari \& Saxena, 2012, p. 671). Organizations use HRM practices to mould the behaviours, attitudes, and perceptions of employees in a way to improve its performance and desired outcomes (Chew, 2004; Juhdi, 2011). However, it must be taken into consideration that HRM practices are not fixed, they differ from one organization to another (Tiwari \& Saxena, 2012). Many researchers defined different practices that are associated with HRM; nevertheless, those practices can be grouped into various categories such as recruitment, selection, training and development, motivation, and maintenance. This paper discusses human resources practices with a focus on four major practices which include recruitment methods, training and development, performance appraisals, and reward systems (Lim \& Ling, 2012).

\subsubsection{Recruitment Methods}

In order for organizations to be successful they need to attract the best employees through the core staffing activity of recruitment (Darrag et al., 2010). However, in practice, this is not as simple as it sounds (O'Leary et al., 2002; Mess, 2004). The aim of recruitment is to obtain the right number of qualified employees to satisfy the need of organizations for human resources (Fong et al., 2011). Therefore, various recruitment methods are used to fulfill this purpose. Recruitment methods can be either internal or external (DeCenzo \& Robbins, 2013) but most organizations tend to focus on three external methods which are advertising, online recruitment, and the use of employment agencies which are found to increase the probability of recruiting talented employees (Armstrong, 2006; Lim \& Ling, 2012).

\subsubsection{Training and Development}

Due to the numerous challenges employees face in the work environment and because human beings are 
considered valuable assets of an organization, organizations need to invest in the training and development of their human capital to enhance their capabilities and abilities (Jimenez \& Valle, 2013). The motive behind having training and development is to increase and update the skills, knowledge and experiences of an organization's employees (Fong et al., 2011). In addition, studies proved that training and development increase employees' productivity and commitment which in turn improves a firm's performance (Vlachos, 2009). These training and development programs are conducted by qualified trainers who can come from inside the organization or from external agencies. Hiring either trainer has its advantages and disadvantages; for example using an external trainer is expensive but ensures the effective delivery of the required knowledge, on the other hand, using an internal trainer costs an organization almost nothing but doesn't ensure that presentations will be successful (Lim \& Ling, 2012).

\subsubsection{Performance Appraisals}

Given current circumstances organizations are paying particular attention to one specific HRM practice that influences an organizations' performance which is performance appraisal (Chen \& Eldridge, 2010). Even though performance appraisals are considered a necessity, both appraisers and appraises dread the entire process (Lim \& Ling, 2012). However, according to DeCenzo \& Robbins (2013) conducting performance appraisals serve three important purposes: 1) providing two-way feedback between employees and supervisors 2) Developing employees and improving their performance 3) Documenting employees' performance for legal reasons. In addition, performance appraisals serve as a basis for certain organizational decisions such as determining pay packages and promotions (Sripirabaa \& Krishnaveni, 2009).

\subsubsection{Reward Systems}

Contributions made to an organization by its employees and their achievements should be recognized and reciprocated by some form of reward (Rudge, 2011). A reward system is defined as "a package/systems that consist of rewards and benefits, such as holiday leaves, medical benefits, transport allowance, and performance bonus" (Lim \& Ling, 2012, p. 104). Reward systems usually serve several purposes which include attracting, retaining, and motivating employees. (Zhou et al., 2011). In addition, researchers such as Yap et al. (2009) found that reward systems have a positive impact on employee performance. Although rewarding employees can be based on one or more factors such as performance, experience, qualification, and seniority (Lim \& Ling, 2012), the most dominant factor used in organizations is performance where employees' performance is linked to expected rewards (Zaitouni et al., 2011; Vlachos, 2009).

\subsection{Organizational Commitment}

Organizations are becoming increasingly interested in the promotion of commitment among employees (Lew, 2011) because of the various benefits associated with it such as improved employee performance and reduced employee turnover (Yew, 2013). Many definitions have been provided for organizational commitment by different researchers, according to Imran \& Ahmed (2012) organizational commitment is defined as "the strength of an individual's identification and involvement with a particular organization" (p. 81). From the various definitions found in the literature, organizational commitment can be interpreted as an individual's link to an organization (Suma \& Lesha, 2013) and the belief in its goals and making the effort to reach those goals by remaining part of that organization (Zaitouni et al., 2011).

Various studies explored organizational commitment in different ways, one study conducted by Mathieu \& Zajac (1990) discovered that organizational commitment was composed of two components, attitudinal and behavioural (Qaisar et al., 2012). Attitudinal commitment is related to how people view their values and goals in relation to their organizations. Whereas, behavioural commitment refers to a person's attachment to an organization no matter the consequences associated with that attachment (Cistulli et al., 2012). In addition, Ortega-Para \& Sastre-Castillo (2013) identified three components that comprise organizational commitment which include the belief and acceptance of an organization's values and goals, the willingness to assist and aid organizations, and the desire to remain part of an organization. However, the most dominant study in the field of organizational commitment is the one conducted by Allen \& Meyer (1990) (Jaros, 2007) which states that organizational commitment consists of three components or dimensions: 1) Affective commitment 2) Continuance commitment 3) Normative commitment (Cho \& Huang, 2012). The researchers wanted to demonstrate how an individual belongs to an organization in terms of emotional, psychological and behavioural dimensions (Cistulli et al., 2012). This paper discusses organizational commitment in terms of the three components proposed by Allen \& Meyer (1990) which include affective commitment, continuance commitment, and normative commitment (Jaros, 2007). 


\subsubsection{Affective Commitment}

Affective commitment is considered to be the most researched component due to the benefits associated with it (Newman \& Sheikh, 2012) such as greater job performance (Cestulli, 2012). Affective commitment is defined as the identification with and emotional attachment employees have with organizations and which occurs because employees want to stay in their organizations (Cho \& Huang, 2012). Organizations can build affective commitment by providing open communication, access to information and allowing employees to participate in decision making (Suma \& Lesha, 2013). Riveros \& Tsai (2011) mentioned that experiences that contribute to a person feeling comfortable and competent in their job are considered antecedents of affective commitment.

\subsubsection{Continuance Commitment}

The more resources employees accumulate over time and could risk losing by leaving the organization, the greater the commitment one will have to the organization (Ling \& Wang, 2012). Continuance commitment is defined as "the extents to which employees feel commitment to their organization when they consider the cost of leaving the organization" (Anari, 2012, p. 258) and usually when individuals feel a need to stay in an organization (Suma \& Lesha, 2013). However, if employees incur the costs of leaving an organization but were not aware of them, then it can be said that continuance commitment does not exist (Jaros, 2007). Studies showed that two factors comprise what is known as continuance commitment, these factors are the number of investments made by an individual and the lack of alternative employment opportunities (See for example, Riveros \& Tsai, 2011; Cho \& Huang, 2012).

\subsubsection{Normative Commitment}

Normative commitment is experienced when an individual feels that he/she has to work for an organization for ethical reasons and the idea of leaving the organization is out of the question (Sayğan, 2011). Many researchers such as Zaitouni (2011), Cho \& Huang (2012), and Saxon (2012) have all provided a similar definition of normative commitment where it is defined as a feeling of moral obligation to remain within an organization. In addition, Qaisar et al. (2012) stated that normative commitment takes place when employees believe they ought to perform a specific task or job. Riveros \& Tsai (2011) mentioned that normative commitment is influenced by the socialization process that takes place prior and after the entering of an organization. In addition, further study conducted by Meyer et al. (2006) posited two dimensions relating to normative commitment; which are indebted obligation which refers to the meeting of expectations set by others, and moral imperative which reflects meeting valued outcomes (Jaros, 2007).

\subsection{Knowledge Management (KM) Process}

Recently, intangible assets have come to play a key role in helping organizations achieve a competitive advantage. Many studies indicated the increased importance of one particular intangible asset which is knowledge (Jimenez-Jimenez \& Sanz-Valle, 2013). Knowledge is becoming an important factor in production in addition to other factors of land, labour, and capital (Rašula et al., 2012). Knowledge can be defined as the information, facts, and concepts that usually reside in practices, norms, processes, documents, and the expertise and experience of individuals, which are required for performing tasks (Kim \& Lee, 2010). Therefore, researchers have come to the agreement that managing knowledge is vital to the success of organizations (Jimenez-Jimenez \& Sanz-Valle, 2013), even though it is not an easy task (Edwards, 2011). While literature provides many definitions of knowledge management, the most basic way KM can be defined is "any process or practice of creating, acquiring, capturing, sharing, and using knowledge, wherever it resides, to enhance learning and performance in organizations" (Armstrong, 2006, p. 174). From the various definitions KM is considered to be a process comprised of several phases or activities (Kim \& Lee, 2010).Various researchers viewed the processes associated with KM differently for example Bousa \& Venkitchalam (2013) described the KM process as the creation, transfer, storage and reuse of knowledge. Pinho et al. (2012) considered the KM process as the process of acquiring, creating, utilizing, and sharing of knowledge. In addition, Allameh et al. (2011) stated that $\mathrm{KM}$ is comprised of the processes of identification, capturing, sharing, disseminating, application, and storing of knowledge. This paper discusses the KM process according to Huber's model which was developed in 1991 and adopted by Jimenez-Jimenez \& Sanz-Valle (2013). This model includes four phases: knowledge acquisition, knowledge distribution, knowledge interpretation, and organizational memory (Jimenez-Jimenez \& Sanz-Valle, 2013).

\subsubsection{Knowledge Acquisition}

Knowledge acquisition refers to the process of obtaining new knowledge and information. This new knowledge can be acquired from internal sources or external sources to the organization. However, regardless of the source 
the most important determinant to this process is the motivation to find and create new knowledge by employees (Kim \& Lee, 2010; Jimenez-Jimenez \& Sanz-Valle, 2013). Organizations can acquire new knowledge using several methods such as through congenital learning which refers to inherited knowledge from the founders of a firm, experiential learning which is knowledge acquired from experience, and vicarious learning which is knowledge acquired from other individuals and businesses (Jashapara, 2011) where Parker (2012) noted that creating relationships and alliances with different partners can positively influence an organization's ability to acquire knowledge.

\subsubsection{Knowledge Distribution}

The ability to distribute and share knowledge is critical for the use and leverage of knowledge resources which are considered important resources to most organizations (Geiger \& Schrevogg, 2012). Knowledge distribution refers to the process of sharing acquired knowledge from one person or unit to another within an organization (Michailova \& Gupta, 2005; Jimenez-Jimenez \& Sanz-Valle, 2013). According to researchers such as Cyr \& Choo (2010) many factors affect the process of sharing knowledge in an organization which include the culture of the organization, the attitudes and values of individuals towards knowledge sharing and the nature of the technology used to share knowledge. Indeed, organizational culture has been defined as the specific collection of values and norms that are shared by people and groups in an organization and that control the way they interact with each other and with stakeholders outside the organization (Al Azmi et al., 2012; Alkalha et al., 2012; Obeidat et al. 2012; Shannak, Obeidat, \& Masa'deh, 2012). Further, researchers have shown that two facets comprise knowledge distribution, which are knowledge disseminating which refers to an individual's desire to share knowledge; and knowledge receiving which refers to the requesting of individuals to share what they know (Kamasak \& Bulutlar, 2010). In addition, Fong \& Choi (2009) found that a major obstacle to the process of knowledge sharing is the trust present between individuals.

\subsubsection{Knowledge Interpretation}

Once knowledge is acquired, interpretation of that knowledge is needed in order for employees to better understand it (Jimenez-Jimenez \& Sanz-Valle, 2013). Knowledge interpretation is defined as "the process through which organizations make sense of new information that they have acquired and disseminated" (Flores et al., 2012, p. 643). Organizations seeking to interpret information should utilize both human and electronic means of communication (Škerlavaj et al., 2010). According to Huber (1991), knowledge interpretation is affected by various constructs including; cognitive maps (existing knowledge background), media richness (methods used to communicate knowledge), information overload, and unlearning (discarding of useless information) (Jashapara, 2011). In addition, Ul Quresh \& Uppatumwichian (2008) mentioned that the process of knowledge interpretation is influenced by the beliefs held by different individuals and groups.

\subsubsection{Organizational Memory}

Memory is considered a prerequisite for organizational success (Girard, 2009). However, it is known that organizations frequently suffer from memory loss or what is called corporate amnesia (Hamidi \& Jusoff, 2009). Therefore, organizational memory has come to play an important role in creating a competitive advantage for organizations (Vrincianu et al., 2009). Akgun et al. (2012) referred to organizational memory as "an aspect of an organization's history in which firms' knowledge are captured and stored in such a way that they become accessible in the future" (p. 97). Jashapara (2011) mentioned two constructs for organizational memory, first, the storing and retrieving of information. Regarding this construct Morrissey (2005) suggested that the tools used to store knowledge are of little significance, what matters are the location and format in which knowledge is stored in as they must be easily found and accessed by employees to retrieve required information. Second, computer-based organizational memory, in this construct technology infrastructure plays an important role such as data centres and software (Cegarra-Navarro et al., 2010).

\section{Research Methodology}

The goal of this research is to investigate the relationship between human resources practices on knowledge management process within organizations. It also investigates the relationship between human resources management practices and their relationship with organizational commitment, and their relationship with Knowledge management process within organizations.

Human resources management practices were measured using recruitment methods, training and development, performance appraisals, and reward systems (Lim \& Ling, 2012). Organizational commitment was measured using three dimensions of affective commitment, continuance commitment, and normative commitment (Allen \& Meyer, 1990). Finally, knowledge management process was measured using four phases of knowledge 
acquisition, knowledge distribution, knowledge interpretation, and organizational memory (Jimenez-Jimenez \& Sanz-Valle, 2013).

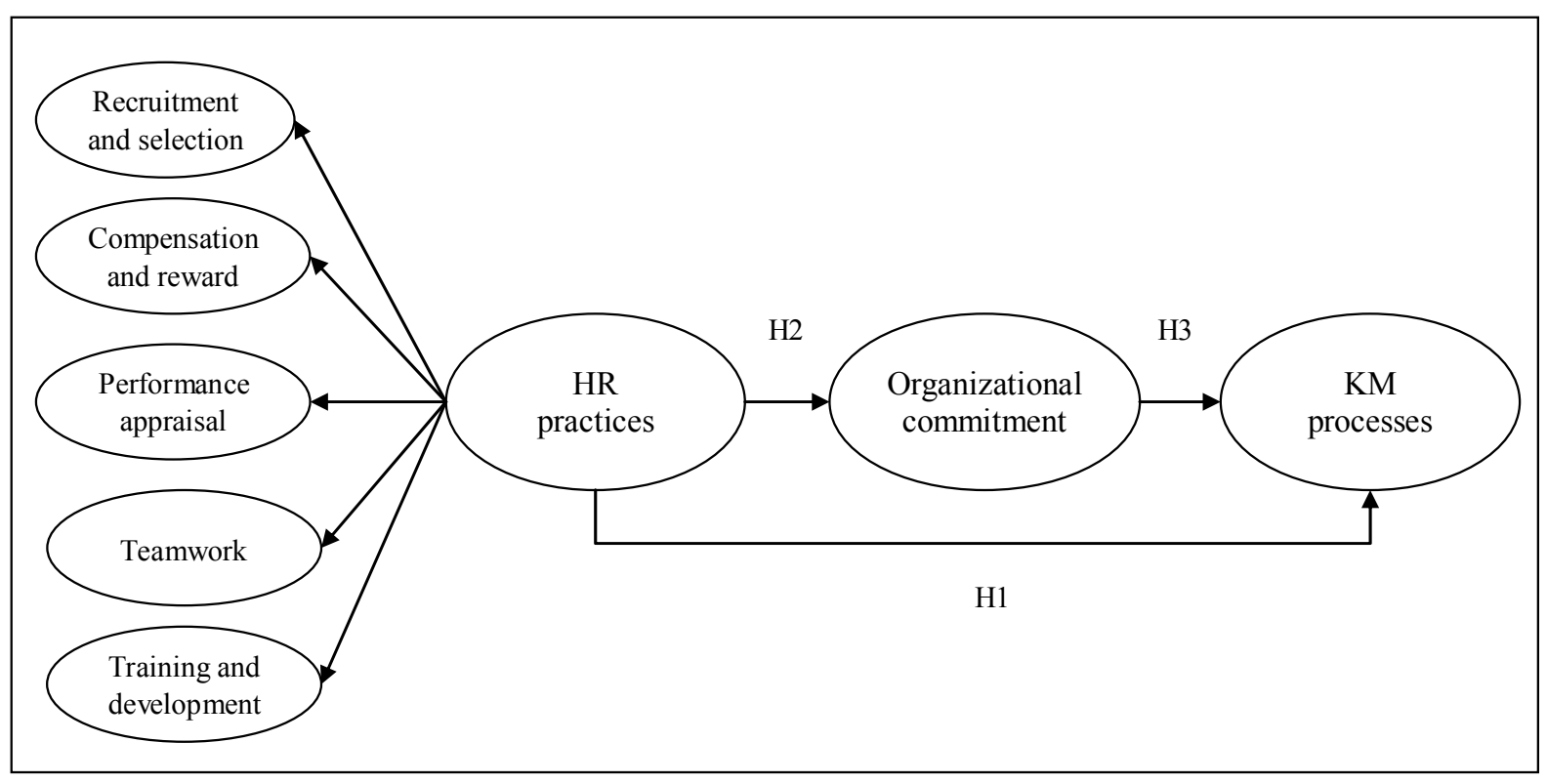

Figure 1. The research model

To achieve the goals of this study, three main hypotheses are developed. Such hypotheses are:

Hypothesis (1): There is a relationship between human resource management practices and knowledge management process.

Hypothesis (2): There is a relationship between human resource management practices and organizational commitment.

Hypothesis (3): There is a relationship between organizational commitment and knowledge management process.

\subsection{Research Sample and Data Collection}

Human resource management, organizational commitment, and the knowledge management process play a significant role in performance of consultancy firms and their ability to achieve and sustain a competitive advantage (Powell \& Ambrosini, 2012). This was supported by Lahti \& Beyerlein (2000) who asserted on the fact that the success of such firms depends merely on the knowledge and ability of their employees to deliver solutions to their customers. Accordingly, the population of this study is composed of all the consultancy firms that operate in Jordan (management, engineering, legal, technological, accounting, training, human resources, financial, and so on) (Suradi, 2013).

In order to test the hypotheses and achieve the objectives of this research, structured questionnaire was used as a collection data method. This questionnaire is composed of 54 questions that represent all the variables of this research. Further, 400 consultancy firms are operating in Jordan with Amman to be the main location of them. Due to the difficulty associated with reaching and accessing such firms, a random sample was selected with 220 questionnaires that were distributed to the firms. Moreover, in order to ensure a high response rate, a cover letter accompanied each questionnaire to respondents explaining the research objectives with the assurance of the confidentiality of the information they provided. Each cover letter was sent directly to the firms' employees, and they were asked to fill in the survey. This letter offered a brief introduction to the research and its objectives, and requested permission to conduct the research. However, 207 questionnaires were submitted back with a response rate of $52 \%$.

Indeed, whether the sample size is sufficient for the estimation of regression analysis is a debatable issue. While Hair et al. (1995) recommended that a feasible sample size should be between 100 and 200, in order to be adequate for the data analysis, Krejcie \& Morgan (1970) who provided guidelines for sample size decision, 
required 201 for a population of 420. Thus, 207 returned surveys indicate an adequate representation.

In this study, the researchers developed a field study for employees. That is as a basis for data collection and analysis; respondents answered all items on five point Likert-scales ranging from "1" of "strongly disagree" to "5" of "strongly agree". Further, elements used to consider each of the constructs were primarily obtained from prior research. These elements provided a valued source for data gathering and measurement as their reliability and validity have been verified through previous research and peer review.

\section{Data Analysis}

The results of this study show that the total number of respondents was 207 employees, $68 \%$ were male and $32 \%$ females, most of them holding a bachelor degree, about $51 \%$ of them are of ages between 20 -less than 30 years old, and about $29 \%$ between 30 -less than 40 years old. The data also revealed that about $65 \%$ of them have experience up to 10 years. Also, in order to examine the research hypotheses, the current study employed Structural Equation Modeling (SEM) techniques with Analysis of Moment Structures (AMOS) 6 software for data analysis. SEM can be divided into two sub-models: a measurement model and a structural model. While the measurement model defines relationships between the observed and unobserved variables, the structural model identifies relationships among the unobserved/latent variables by specifying which latent variables directly or indirectly influence changes in other latent variables in the model (Byrne, 2001). Furthermore, the structural equation modeling process consists of two components: validating the measurement model and fitting the structural model. While the former is accomplished through confirmatory factor analysis, the latter is accomplished by path analysis with latent variables (Kline, 2005).

Table 1 demonstrates different types of goodness of fit indices in assessing this study initial specified model. It displays that the research constructs fits the data according to the absolute, incremental, and parsimonious model fit measures, comprising chi-square per degree of freedom ratio ( $\left.\mathrm{x}^{2} / \mathrm{df}\right)$, Incremental Fit Index (IFI), TuckerLewis Index (TLI), Comparative Fit Index (CFI), and Root Mean Square Error of Approximation (RMSEA). Furthermore, the researchers examined the standardized regression weights for the research's indicators and found that some indicators had a low loading towards the latent variables. In particular $(\mathrm{RS} 4=0.410, \mathrm{AC} 3=$ $0.401, \mathrm{CC} 7=0.381, \mathrm{NC} 5=0.373$ ). Moreover, since both items did not meet the minimum recommended value of factor loadings of 0.50 (Newkirk \& Lederer, 2006), and because the initial fit indices were fit the sample data, then they were removed and excluded from further analysis. Therefore, the measurement model was modified and showed a better fit to the data (as shown in Table 1). For instance, $\mathrm{x}^{2} / \mathrm{df}$ and RMSEA did change for the final model, the IFI $=0.901$, TLI $=0.902$, and CFI $=0.901$ indicated better fit to the data after removing the low factor loading items.

Table 1. Measurement model fit indices

\begin{tabular}{lllllllll}
\hline Model & $\mathrm{x}^{2}$ & $\mathrm{df}$ & $\mathrm{P}$ & $\mathrm{x}^{2} / \mathrm{df}$ & $\mathrm{IFI}$ & $\mathrm{TLI}$ & $\mathrm{CFI}$ & RMSEA \\
\hline Initial Estimation & 1019.153 & 355 & 0.000 & 2.870 & 0.888 & 0.892 & 0.888 & 0.055 \\
Final Model & 846.332 & 306 & 0.000 & 2.765 & 0.901 & 0.902 & 0.901 & 0.053 \\
\hline
\end{tabular}

\subsection{Measurement Model}

Once modifying the final measurement model for all constructs, the next phase is to evaluate them for unidimensionality, reliability, and validity. Indeed, the outcomes of the measurement model are presented in Table 2, encapsulates the standardized factor loadings, measures of reliabilities and validity for the final measurement model.

\subsection{Unidimensionality}

Unidimensionality states to the extent to which the study indicators form their latent variable. An examination of the unidimensionality of the research constructs is essential and an important prerequisite for establishing construct reliability and validity analysis (Chou et al., 2007). Also, in line with Byrne (2001), this research assessed unidimensionality using the factor loading of items of their respected constructs. Table 2 shows solid evidence for the unidimensionality of all the constructs that specified in the measurement model. All loadings (except RS4, AC3, CC7, and NC5) were above 0.50, the criterion value recommended by Newkirk \& Lederer (2006). These loadings confirmed that 50 (out of 54) items were loaded satisfactory on their constructs.

\subsection{Reliability}

Reliability analysis is related to the assessment of the degree of consistency between multiple measurements of a 
variable, and could be measured by Cronbach alpha coefficient and composite reliability (Hair et al., 1998). Furthermore, some scholars (e.g, Bagozzi \& Yi, 1988) suggested that the values of all indicators or dimensional scales should be above the recommended value of 0.60. Table 2 indicates that all Cronbach alpha values for the twelve constructs exceeded the recommended value of 0.60 (Bagozzi \& Yi, 1988) demonstrating that the instrument is reliable. Also, as shown in Table 2, composite reliability values ranged from 0.92 to 0.95 , and were all greater than the recommended value of more than 0.60 (Bagozzi \& Yi, 1988) or greater than 0.70 as suggested by Holmes-Smith (2001). Consequently, according to the above two tests, all the research constructs in this study are considered reliable.

Table 2. Properties of the final measurement model

\begin{tabular}{|c|c|c|c|c|c|c|c|}
\hline $\begin{array}{l}\text { Constructs and } \\
\text { Indicators }\end{array}$ & $\begin{array}{l}\text { Std. } \\
\text { Loading }\end{array}$ & Std. Error & $\begin{array}{l}\text { Square } \\
\text { Multiple } \\
\text { Correlation }\end{array}$ & $\begin{array}{l}\text { Error } \\
\text { Variance }\end{array}$ & $\begin{array}{l}\text { Cronbach } \\
\text { Alpha }\end{array}$ & $\begin{array}{l}\text { Composite } \\
\text { Reliability }\end{array}$ & AVE \\
\hline $\begin{array}{l}\text { Recruitment } \\
\text { selection }\end{array}$ & and & & & & 0.885 & 0.92 & 0.90 \\
\hline RS1 & 0.820 & 0.113 & 0.644 & 0.062 & & & \\
\hline RS2 & 0.872 & 0.124 & 0.635 & 0.065 & & & \\
\hline RS3 & 0.852 & 0.112 & 0.674 & 0.055 & & & \\
\hline RS5 & 0.886 & 0.120 & 0.696 & 0.061 & & & \\
\hline $\begin{array}{l}\text { Compensation } \\
\text { reward }\end{array}$ & and & & & & 0.891 & 0.94 & 0.92 \\
\hline CR1 & 0.882 & 0.107 & 0.578 & 0.071 & & & \\
\hline CR2 & 0.833 & 0.110 & 0.593 & 0.068 & & & \\
\hline CR3 & 0.845 & 0.112 & 0.610 & 0.069 & & & \\
\hline CR4 & 0.822 & 0.113 & 0.607 & 0.072 & & & \\
\hline Performance & & & & & 0.912 & 0.92 & 0.95 \\
\hline Appraisal & & & & & & & \\
\hline PA1 & 0.834 & 0.113 & 0.668 & 0.071 & & & \\
\hline PA2 & 0.885 & 0.110 & 0.627 & 0.068 & & & \\
\hline PA3 & 0.839 & 0.109 & 0.665 & 0.064 & & & \\
\hline Teamwork & & & & & 0.922 & 0.95 & 0.92 \\
\hline TW1 & 0.734 & 0.114 & 0.679 & 0.066 & & & \\
\hline TW2 & 0.744 & 0.113 & 0.703 & 0.062 & & & \\
\hline TW3 & 0.735 & 0.109 & 0.701 & 0.063 & & & \\
\hline $\begin{array}{l}\text { Training } \\
\text { development }\end{array}$ & and & & & & 0.878 & 0.91 & 0.94 \\
\hline TD1 & 0.779 & 0.111 & 0.712 & 0.069 & & & \\
\hline TD2 & 0.772 & 0.109 & 0.707 & 0.067 & & & \\
\hline TD3 & 0.769 & 0.107 & 0.705 & 0.063 & & & \\
\hline $\begin{array}{l}\text { Affective } \\
\text { commitment }\end{array}$ & & & & & 0.944 & 0.94 & 0.90 \\
\hline $\mathrm{AC} 1$ & 0.658 & 0.165 & 0.661 & 0.071 & & & \\
\hline $\mathrm{AC} 2$ & 0.666 & 0.161 & 0.672 & 0.063 & & & \\
\hline $\mathrm{AC} 4$ & 0.679 & 0.173 & 0.645 & 0.065 & & & \\
\hline AC5 & 0.691 & 0.175 & 0.661 & 0.069 & & & \\
\hline AC6 & 0.683 & 0.177 & 0.701 & 0.070 & & & \\
\hline $\mathrm{AC} 7$ & 0.702 & 0.169 & 0.679 & 0.072 & & & \\
\hline $\mathrm{AC} 8$ & 0.704 & 0.168 & 0.698 & 0.069 & & & \\
\hline $\begin{array}{l}\text { Continuance } \\
\text { commitment }\end{array}$ & & & & & 0.936 & 0.92 & 0.93 \\
\hline $\mathrm{CC} 1$ & 0.789 & 0.108 & 0.701 & 0.061 & & & \\
\hline $\mathrm{CC} 2$ & 0.817 & 0.111 & 0.704 & 0.063 & & & \\
\hline $\mathrm{CC} 3$ & 0.811 & 0.109 & 0.695 & 0.071 & & & \\
\hline $\mathrm{CC} 4$ & 0.797 & 0.101 & 0.679 & 0.069 & & & \\
\hline $\mathrm{CC} 5$ & 0.778 & 0.107 & 0.701 & 0.067 & & & \\
\hline
\end{tabular}




\begin{tabular}{|c|c|c|c|c|c|c|c|}
\hline CC6 & 0.801 & 0.112 & 0.711 & 0.069 & & & \\
\hline CC8 & 0.787 & 0.116 & 0.695 & 0.074 & & & \\
\hline $\begin{array}{l}\text { Normative } \\
\text { commitment }\end{array}$ & & & & & 0.841 & 0.95 & 0.92 \\
\hline $\mathrm{NC} 1$ & 0.805 & 0.106 & 0.791 & 0.077 & & & \\
\hline $\mathrm{NC} 2$ & 0.821 & 0.111 & 0.783 & 0.081 & & & \\
\hline $\mathrm{NC} 3$ & 0.823 & 0.121 & 0.689 & 0.072 & & & \\
\hline $\mathrm{NC} 4$ & 0.802 & 0.114 & 0.684 & 0.073 & & & \\
\hline NC6 & 0.846 & 0.113 & 0.732 & 0.074 & & & \\
\hline $\mathrm{NC} 7$ & 0.847 & 0.109 & 0.738 & 0.079 & & & \\
\hline $\mathrm{NC} 8$ & 0.856 & 0.111 & 0.701 & 0.082 & & & \\
\hline $\begin{array}{l}\text { Knowledge } \\
\text { acquisition }\end{array}$ & & & & & 0.856 & 0.94 & 0.94 \\
\hline KA1 & 0.668 & 0.182 & 0.473 & 0.078 & & & \\
\hline KA2 & 0.711 & 0.178 & 0.446 & 0.079 & & & \\
\hline KA3 & 0.701 & 0.177 & 0.511 & 0.083 & & & \\
\hline $\begin{array}{l}\text { Knowledge } \\
\text { distribution }\end{array}$ & & & & & 0.799 & 0.94 & 0.90 \\
\hline KD1 & 0.687 & 0.186 & 0.553 & 0.088 & & & \\
\hline $\mathrm{KD} 2$ & 0.761 & 0.182 & 0.543 & 0.087 & & & \\
\hline KD3 & 0.721 & 0.187 & 0.576 & 0.079 & & & \\
\hline $\begin{array}{l}\text { Knowledge } \\
\text { interpretation }\end{array}$ & & & & & 0.810 & 0.95 & 0.93 \\
\hline KI1 & 0.866 & 0.177 & 0.652 & 0.070 & & & \\
\hline KI2 & 0.873 & 0.167 & 0.721 & 0.073 & & & \\
\hline KI3 & 0.811 & 0.172 & 0.742 & 0.076 & & & \\
\hline $\begin{array}{l}\text { Organizational } \\
\text { memory }\end{array}$ & & & & & 0.923 & 0.94 & 0.94 \\
\hline OM1 & 0.808 & 0.171 & 0.687 & 0.084 & & & \\
\hline OM2 & 0.821 & 0.179 & 0.679 & 0.082 & & & \\
\hline OM3 & 0.811 & 0.173 & 0.682 & 0.078 & & & \\
\hline
\end{tabular}

\subsection{Content, Convergent, and Discriminant Validity}

Although reliability is considered as a necessary condition of the test of goodness of the measure used in research, it is not sufficient (Sekaran, 2003), thus validity is another condition used to measure the goodness of a measure. Validity refers to which an instrument measures is expected to measure or what the researcher wishes to measure (Blumberg et al., 2005). Indeed, the items selected to measure the five HR practices variables (recruitment and selection, compensation and reward, performance appraisal, teamwork, training and development) besides the other variables (i.e., affective commitment, continuance commitment, normative commitment, knowledge acquisition, knowledge distribution, knowledge interpretation, and organizational memory) were validated and reused from previous researches. Therefore, the researchers relied upon in enhancing the validity of the scale was to benefit from a pre-used scale that is developed from other researchers. Also, the questionnaire items were reviewed by seven instructors of the Business Faculty at the University of Jordan. The feedback from the chosen group for the pre-test contributed to enhanced content validity of the instrument. Moreover, in order to enhance the content validity of the instrument, six employees from the industry were asked to give their feedback about the questionnaire, thus confirming that the knowledge presented in the content of each question was relevant to the studied topic.

In addition, as convergent validity test is necessary in the measurement model to determine if the indicators in a scale load together on a single construct; discriminant validity test is another main one to verify if the items that developed to measure different constructs are certainly evaluating different constructs. As shown in Table 2, all items were significant and had loadings more than 0.50 on their underlying constructs. Moreover, the standard errors for the items ranged from 0.101 to 0.187 and all the item loadings were more than twice their standard error. Further, discriminant validity was considered using several tests. First, it could be examined in the measurement model by investigating the shared average variance extracted (AVE) by the latent constructs. Also, the correlations among the research constructs could be used to assess discriminant validity by examining if 
there is any extreme large correlations among them which imply that the model have a problem of discriminant validity. Also, if the AVE for each construct exceeds the square correlation between that construct and any other constructs then discriminant validity is occurred (Fornell \& Larcker, 1981). As shown in Table 2, this study showed that the AVEs of all the constructs were above the suggested level of 0.50, implying that all the constructs that ranged from 0.90 to 0.95 were responsible for more than 50 percent of the variance in their respected measurement items, which met the recommendation that AVE values should be at least 0.50 for each construct (Bagozzi \& Yi, 1988; Holmes, 2001). Moreover, as shown in Table 3, discriminant validity was confirmed as the AVE values were more than the squared correlations for each set of constructs. Thus, the measures significantly discriminate between the constructs.

Table 3. AVE and square of correlations between constructs (cons.)

\begin{tabular}{|c|c|c|c|c|c|c|c|c|c|c|c|c|}
\hline Cons. & RS & $\mathrm{CR}$ & PA & TW & TD & $\mathrm{AC}$ & $\mathrm{CC}$ & $\mathrm{NC}$ & KA & $\mathrm{KD}$ & KI & $\mathrm{OM}$ \\
\hline (RS) & 0.90 & & & & & & & & & & & \\
\hline (CR) & 0.55 & 0.92 & & & & & & & & & & \\
\hline (PA) & 0.62 & 0.41 & 0.95 & & & & & & & & & \\
\hline (TW) & 0.64 & 0.52 & 052 & 0.92 & & & & & & & & \\
\hline (TD) & 0.56 & 0.54 & 0.61 & 0.49 & 0.94 & & & & & & & \\
\hline (AC) & 0.53 & 0.43 & 0.43 & 0.44 & 0.52 & 0.90 & & & & & & \\
\hline (CC) & 0.44 & 0.52 & 0.52 & 0.47 & 0.49 & 0.57 & 0.93 & & & & & \\
\hline$(\mathrm{NC})$ & 0.66 & 0.49 & 0.45 & 0.52 & 0.45 & 0.52 & 0.48 & 0.92 & & & & \\
\hline (KA) & 0.53 & 0.43 & 0.47 & 0.51 & 0.52 & 0.49 & 0.47 & 0.55 & 0.94 & & & \\
\hline (KD) & 0.62 & 0.53 & 0.49 & 0.53 & 0.53 & 0.48 & 0.42 & 0.48 & 0.62 & 0.90 & & \\
\hline (KI) & 0.63 & 0.49 & 0.52 & 0.52 & 0.54 & 0.42 & 0.53 & 0.47 & 0.53 & 0.59 & 0.93 & \\
\hline$(\mathrm{OM})$ & 0.61 & 0.52 & 0.53 & 0.53 & 0.53 & 0.52 & 0.55 & 0.53 & 0.55 & 0.56 & 0.59 & 0.94 \\
\hline
\end{tabular}

\subsection{Structural Model}

Following the two-phase SEM technique, the measurement model results were used to test the structural model, including paths representing the proposed associations among research constructs. Furthermore, in order to examine the structural model it is essential to investigate the statistical significance of the standardized regression weights (i.e. t-value) of the research hypotheses (i.e. the path estimations) at 0.05 level (see Table 4); and the coefficient of determination $\left(\mathrm{R}^{2}\right)$ for the research endogenous variables as well. Indeed, the coefficient of determination for organizational commitment, and KM practices were 0.421 and 0.534 respectively, indicates that the model moderately accounts for the variation of the proposed model.

Table 4. Summary of proposed results for the theoretical model

\begin{tabular}{llll}
\hline Research Proposed Paths & Coefficient & t-value & p-value \\
& Value & & Empirical \\
\hline H1: HR practices $\rightarrow$ KM processes & 0.091 & 0.878 & 0.445 \\
H2: HR practices $\rightarrow$ Organizational commitment & 0.665 & 2.554 & 0.000 \\
H3: Organizational commitment $\rightarrow$ KM processes & 0.763 & 2.768 & 0.000 \\
\hline
\end{tabular}

\section{Discussion Results and Conclusion}

Taking into consideration the three hypotheses of this study, this section is divided into three parts. The first part is associated with the first hypothesis and deals with the relationship between HRM practices and KM process. The second part deals with HRM practices and their relationship with organizational commitment. Finally, the third part is associated with the third hypothesis and deals with the relationship between organizational commitment and KM process.

\subsection{HRM Practices and KM Processes}

The results of this study do not support the first hypothesis and show that there is no relationship between HRM practices and KM process. This might be explained to the existence of other factors than human resources that organizations and managers in consultancy firms in Jordan adopt to enhance knowledge management process. 
The results of this study do not agree with what was found by Jimenez-Jimenez \& Sanz-Valle (2013). According to them, the relation between HRM and KM does exist and that a knowledge-oriented HR system that includes the practices of job design, team work, staffing, career development, training, performance appraisal and compensation may enhance all the KM processes of knowledge acquisition, knowledge distribution, knowledge interpretation and organizational memory. In addition, their findings highlight the importance of adopting knowledge-oriented HR practices not in an isolated manner but forming a system of consistent HRM practices. They added that individual HRM practices do not affect all the KM processes, however, when they are adopted together, as a system, they foster knowledge acquisition, distribution, interpretation and storing. This was also supported by Fong et al. (2011) who mentioned that not all HRM practices are appropriate to enhance the KM process of knowledge sharing. According to their study knowledge sharing is positively influenced by recruitment and selection, teamwork, training and development, and performance appraisal. Nevertheless, compensation had no significant association with knowledge sharing.

The results of this study can be also explained by the fact that managers do not take KM process seriously. This can be supported by Oltra's (2005) results who asserted on the fact that unless HRM and KM have been both taken seriously by management, there is little need to talk about the role of HRM practices in KM. This was discussed by Hislop (2003) who looked at it from employees' point of view and concluded that the type of HRM policies and practices adopted in an organization has been found to affect people's willingness to share knowledge.

\subsection{HRM Practices and Organizational Commitment}

The results of this study do support the second hypothesis and found a relationship between HRM practices and organizational commitment. This might be explained to the fact that the more valid and reliable human resource practices are, the higher the probability of adapting new employees to organizations, the lower the turnover is, the higher the organizational commitment will be (DeCenzo \& Robbins, 2013).

Furthermore, the results of this study agree with what was found in Juhdi \& his colleague's study carried out in 2011. According to them, all four HR practices of performance appraisal, career management, person-fit (presented in training and development), and compensation are positively related to organizational commitment. This was also supported by many studies. In their study, Imran \& Ahmed (2012) showed that HR practices of compensation, perceived organizational support, work life policies, training and development, career opportunities, empowerment, organizational climate and communication have a direct and positive impact on organizational commitment. Furthermore, Edgar \& Geare (2005) study results showed that a significant relationship exists between HRM practices and employee work-related attitudes which include organizational commitment, job satisfaction, and organizational fairness. Sanders et al. (2008) asserted on the importance of human resource as a factor within organizations and stated that employees that perceive the HRM system of an organization as distinct tend to be more affective committed to the organization. Finally, the results of this study do not partially agree with the result of the study carried out by Zaitouni et al. (2011). Zaitouni \& his colleagues found that HRM practices which include competence development, fair rewards, and information sharing were positively and significantly related to affective commitment. However, only the practices of fair rewards and information sharing were significantly related to continuance commitment. In addition, Information sharing was the only practice positively related to normative commitment.

\subsection{Organizational Commitment and KM Processes}

The results of this study show a positive relationship between organizational commitment and knowledge management process. This might be explained by the fact that employees would not exert any effort to acquire, share, interpret, and share information and knowledge unless they felt important within organizations, accordingly being committed to it. In addition, the results of this study agree with what was found by Thompson \& Heron (2005) who mentioned that high levels of knowledge worker commitment are critical to knowledge creation, because the importance of these workers has been shown for the creation and sharing of knowledge. This was also supported by many studies. For example, Neyestani \& his colleague's study showed that employees' commitment to an organization represented by the organization's loyalty responsibility, participation in organizational decisions, emotional attachment to the organization, participation in the life of the organization, and supporting organizational goals can have an effect on enhancing and promoting knowledge sharing among employees (2013). A study carried out by Malhotra \& Galletta (2003), claims that motivation and commitment are considered to be important antecedents for the successful implementation of knowledge management systems. Alvesson (2005) suggested that high levels of employees' commitment to the organization contribute to the success of companies in generating and appropriating knowledge. Finally, Chiang et al. (2011) found that 
organizational commitment contributes to the behaviour of knowledge sharing which is considered to be an important behaviour in the knowledge economies. Where a study carried before by Rocha and his colleagues in 2008 support the above arguments and added that the levels of organizational commitment can inhibit or facilitate the KM processes in organizations.

Depending on the results of this study, it can be concluded that human resource management practices have no direct relationship with knowledge management process. However, taking into consideration the existence of a relationship between human resource management practices and organizational commitment, on the one hand, and the existence of a relationship between organizational commitment and knowledge management process, on the other hand, it can be concluded that human resource management practices have a positive relationship with knowledge management process on a condition of having organizational commitment as a mediating variable. This result agrees with what was found by Chiang \& his colleagues in 2011 who concluded that there is a positive relationship between high-commitment HRM practices and knowledge sharing mediated by perceived organizational support and organizational commitment.

\section{Limitations and Future Work}

The results of this study show no direct relationship between HRM practices and KM process. As mentioned earlier, this might be explained by the existence of other factors than human resource practices that might affect KM process. It might be also explained by the fact that the relationship can be motivated by the existence of other moderating variables like organizational commitment and support which opens the door for future research to be carried out on this issue.

Also, several researchers consider the IT and its flexibility as an enabler to achieve the desired competitive advantages, considered as a strategic weapon, and as a crucial support to operational and strategic business processes (Altamony et al., 2012; Masa'deh, 2012; Masa'deh, 2013; Masa'deh, Shannak, \& Maqableh, 2013). Further, some scholars (e.g, Shannak et al., 2010; Masa'deh \& Shannak, 2012; Shannak et al., 2012; Shannak, Masa'deh, \& Alkour, 2012; Kannan et al., 2013; Masa'deh et al., 2013) emphasize the need for large firms to integrate their IT systems with their KM strategies and processes in order to survive in their highly competitive business environments. Therefore, more research is needed to consider the specific role of KM processes on business performance.

A quantitative technique (questionnaire) was used as the main method to collect the data this might be considered as a limitation of this study. More qualitative techniques are recommended to be used to get more accurate data and results to achieve the goals and objectives of this study. Finally, consultancy firms were used as a population to collect the data of this study from. This might cause some generalizability problems since consultancy firms have their own way of carrying out their business. Future research that focuses on more than one industry is recommended to overcome the issue of generalization.

\section{References}

Akgün, A. E., Keskin, H., \& Byrne, J. (2012). Organizational emotional memory. Management Decision, 50(1), 95-114. http://dx.doi.org/10.1108/00251741211194895

Akhavan, P., Ramezan, M., \& Moghaddam, J. Y. (2013). Examining the role of ethics in knowledge management process. Case study: An industrial organization. Journal of Knowledge-Based Innovation in China, 5(2), 129-145. http://dx.doi.org/10.1108/JKIC-04-2013-0008

Al Azmi, N., Al-Lozi, M., Al-Zu'bi, Z., Dahiyat, S., \& Masa'deh, R. (2012). Patients attitudes toward service quality and its impact on their satisfaction in physical therapy in KSA hospitals. European Journal of Social Sciences, 34(2), 300-314.

Al-Suradi, M. (2013). The role of knowledge management in innovation in Jordanian consultancy firms. Unpublished Master Thesis, The University of Jordan.

Allameh, M., Zare, M., \& Davoodi, M. (2011). Examining the impact of KM enablers on knowledge management processes. Procedia Computer Science, 3, 1211-1223. http://dx.doi.org/10.1016/j.procs.2010.12.196

Allen, N. J., \& Meyer, J. P. (1990). The measurement and antecedents of affective, continuance and normative commitment to the organization. Journal of Occupational Psychology, 63, 1-18. http://dx.doi.org/10.1111/j.2044-8325.1990.tb00506.x

Alkalha, Z., Al-Zu'bi, Z., Al-Dmour, H., Alshurideh, M., \& Masa'deh, R. (2012). Investigating the effects of human resource policies on organizational performance: An empirical study on commercial banks 
operating in Jordan. European Journal of Economics, Finance and Administrative Sciences, 51, 44-64.

Altamony, H., Masa'deh, R, Alshurideh, M., \& Obeidat, B. (2012). Information systems for competitive advantage: Implementation of an organisational strategic management process. Proceedings of the 18th IBIMA Conference on Innovation and Sustainable Economic Competitive Advantage: From Regional Development to World Economic, Istanbul, Turkey, 9th-10th May.

Alvesson, M. (2005). Knowledge work: Ambiguity, image and identity. Human Relations, 54, 863-886. http://dx.doi.org/10.1177/0018726701547004

Anari, N. N. (2012). Teachers: emotional intelligence, job satisfaction, and organizational commitment. Journal of Workplace Learning, 24(4), 256-269. http://dx.doi.org/10.1108/13665621211223379

Armstrong, M. (2006). A handbook of human resource management practice. London: Kogan Page.

Bagozzi, R. P., \& Yi, Y. (1988). On the evaluation of structural equation models. Journal of the Academy of Marketing Science, 16(1), 74-94. http://dx.doi.org/10.1007/BF02723327

Bimpitsos, C., \& Petridou, E. (2012). A transdisciplinary approach to training: preliminary research findings based on a case analysis. European Journal of Training and Development, 36(9), 911-929. http://dx.doi.org/10.1108/03090591211280964

Blumberg, B., Cooper, D. C., \& Schindler, P. S. (2005). Business research methods. McGraw-Hill.

Bosua, R., \& Venkitachalam, K. (2013). Aligning strategies and processes in knowledge management: a framework. Journal of Knowledge Management, 17(3), 331-346. http://dx.doi.org/10.1108/JKM-10-2012-0323

Byrne, B. M. (2001). Structural equation modeling With AMOS, EQS, and LISREL: Comparative approaches to testing for the factorial validity of a measuring instrument. International Journal of Testing, 1(1), 55-86. http://dx.doi.org/10.1207/S15327574IJT0101_4

Cegarra-Navarro, J., Cepeda-Carrion, G., \& Jimenez-Jimenez, D. (2010). Linking unlearning with innovation through organizational memory and technology. Electronic Journal of Knowledge Management, 8(1), 1-10.

Chen, J., \& Eldridge, D. (2010). Are "standardized performance appraisal practices" really preferred? A case study in China. Chinese Management Studies, 4(3), 244-257. http://dx.doi.org/10.1108/17506141011074138

Chew, J. C. L. (2004). The influence of human resource management practices on the retention of core employees of Australian organizations: An empirical study. Unpublished Doctoral Dissertation, Murdoch University.

Chiang, H., Han, T., \& Chuang, J. (2011). The relationship between high-commitment HRM and knowledge-sharing behavior and its mediators. International Journal of Manpower, 32(5/6), 604-622. http://dx.doi.org/10.1108/01437721111158224

Cho, V., \& Huang, X. (2012). Professional commitment, organizational commitment, and the intention to leave for professional advancement. Information Technology \& People, 25(1), 31-54. http://dx.doi.org/10.1108/09593841211204335

Chou, T. C., Chang, P. L., Cheng, Y. P., \& Tasi, C. T. (2007). A path model linking organizational knowledge attributes, information processing capabilities, and perceived usability. Information \& Management, 44, 408-417. http://dx.doi.org/10.1016/j.im.2007.03.003

Cistulli, M. D., Snyder, J. L., \& Jacobs, R. (2012). Affective organizational commitment as a predictor of military enlistment discussion and recommendation. International Journal of Business, Humanities and Technology, 2(3), 27-33.

Cyr, S., \& Choo, C. W. (2010). The individual and social dynamics of knowledge sharing: An exploratory study. Journal of Documentation, 66(6), 824-846. http://dx.doi.org/10.1108/00220411011087832

Darrag, M., Mohamed, A., \& Abdel Aziz, H. (2010). Investigating recruitment practices and problems of multinational companies (MNCs) operating in Egypt. Education, Business and Society: Contemporary Middle Eastern Issues, 3(2), 99-116.

DeCenzo, D. A., \& Robbins, S. P. (2013). Human resource management. Asia: Wiley.

Dominguez, A. A. (2011). The impact of human resource disclosure on corporate image. Journal of Human Resource Costing \& Accounting, 15(4), 279-298. http://dx.doi.org/10.1108/14013381111197225 
Edgar, F., \& Geare, A. (2005). HRM practice and employee attitudes: different measures-different results. Personnel Review, 34(5), 534-549. http://dx.doi.org/10.1108/00483480510612503

Edwards, J. (2011). A process view of knowledge management: It ain't what you do, it's the way that you do it. The Electronic Journal of Knowledge Management, 9(4), 297-306.

Flores, L. G., Zheng, W., Rau, D., \& Thomas, C. H. (2012). Organizational learning: Subprocess identification, construct validation, and an empirical test of cultural antecedents. Journal of Management, 38(2), 640-667. http://dx.doi.org/10.1177/0149206310384631

Fong, C., Ooi, K., Tan, B., Lee, V., \& Chong, A. (2011). HRM practices and knowledge sharing: an empirical $\begin{array}{lllll}\text { study. International Journal of } & \text { Manpower, }\end{array}$ http://dx.doi.org/10.1108/01437721111158288

Fong, P., \& Choi, S. (2009). The processes of knowledge management in professional services firms in the construction industry: A critical assessment of both theory and practice. Journal of Knowledge Management, 13(2), 110-126. http://dx.doi.org/10.1108/13673270910942736

Fornell, C., \& Larcker, D. F. (1981). Evaluating structural equation models with unobservable variables and measurement error. Journal of Marketing Research, 18(1), 39-50. http://dx.doi.org/10.2307/3151312

Geiger, D., \& Schreyogg, G. (2012). Narratives in knowledge sharing: Challenging validity. Journal of Knowledge Management, 16(1), 97-113. http://dx.doi.org/10.1108/13673271211198963

Girard, J. P. (2009). Building organizational memories: Will you know what you knew? Hershey, New York: Idea Group Inc. http://dx.doi.org/10.4018/978-1-59904-540-5

Hair, J., Anderson, R., Tatham, R., \& Black, W. (1995). Multivariate data analysis (4th ed.). New Jersey: Prentice-Hall Inc.

Hair, J. F. Jr., Anderson, R., \& Tatham, R. (1998). Multivariate data analysis (5th ed.). Upper Saddle River, NJ: Prentice Hall.

Hamidi, S. R., \& Jusoff, K. (2009). The characteristic and success factors of an organizational memory information system. Computer and Information Science, 2(1), 142-151.

Hislop, D. (2003). Linking human resource management and knowledge management via commitment. Employee Relations, 25(2), 182-202. http://dx.doi.org/10.1108/01425450310456479

Holmes-Smith, P. (2001). Introduction to structural equation modelling using LISREAL. Perth: ACSPRI-Winter training Program.

Huber, G. P. (1991). Organizational learning: The contributing processes and the literatures. Organization Science, 2(1), 88-115. http://dx.doi.org/10.1287/orsc.2.1.88

Imran, A., \& Ahmed, M. (2012). Impact of human resource practices on organizational commitment: A study among service sector employees in Pakistan. Interdisciplinary Journal of Contemporary Research in Business, 4(2), 81-90.

Jaros, S. (2007). Meyer and Allen model of organizational commitment: Measurement issue. Retrieved from $\mathrm{http}: / / \mathrm{www}$. stevejaros.com/wp-content/uploads/2009/08/Jaros-ICFAI-2007-Meyer-and-Allen1.pdf

Jashapara, A. (2011). Knowledge management: An integrated approach. England: Prentice Hall.

Jelenic, D. (2011). The Importance of knowledge management organisations with emphasis on the balanced score card learning and growth perspective: Knowledge as business opportunity. Proceedings of the Management, Knowledge and Learning International Conference, Celje, Slovenia.

Jimenez-Jimenez, D., \& Sanz-Valle, R. (2013). Studying the effect of HRM practices on the knowledge management process. Personnel Review, 42(1), 28-49. http://dx.doi.org/10.1108/00483481311285219

Juhdi, N., Pa'wan, F., Hansaram, R. M., \& Othman, N. A. (2011). HR practices, organizational commitment and turnover intention: A study on employees in Klang Valley, Malaysia. Recent Researches in Applied Economics, 30-36.

Kamasak, R., \& Bulutlar, F. (2010). The influence of knowledge sharing on innovation. European Business Review, 22(3), 306-317. http://dx.doi.org/10.1108/09555341011040994

Kanaan, R., Masa'deh, R., \& Gharaibeh, A. (2013). The impact of knowledge sharing enablers on knowledge sharing capability: An empirical study on Jordanian telecommunication firms. European Scientific Journal, 
$9(22), 237-258$.

Kim, S., \& Lee, H. (2010). Factors affecting employee knowledge acquisition and application capabilities. Asia-Pacific Journal of Business Administration, 2(2), 133-152. http://dx.doi.org/10.1108/17574321011078184

Kline, R. B. (2005). Principles and practice of structural equation modeling (2nd ed.). New York: The Guilford Press.

Krejcie, R. V., \& Morgan, D. W. (1970). Determining sample size for research activities. Educational and Psychological Measurement, 30, 607-610.

Lahti, R. K., \& Beyerlein, M. M. (2000). Knowledge transfer and management consulting: A look at the firm. Business Horizons, 43(1), 65-74. http://dx.doi.org/10.1016/S0007-6813(00)87389-9

Lew, T. Y. (2011). Affective organizational commitment and turnover intention of academics in Malaysia. Proceedings of the International Conference on Business and Economics Research, Kuala Lumpur, Malaysia.

Lim, L. J. W., \& Ling, F. Y. Y. (2012). Human resource practices of contractors that lead to job satisfaction of professional staff. Engineering, Construction and Architectural Management, 19(1), 101-118. http://dx.doi.org/10.1108/09699981211192599

Lin, C., \& Wang, W. (2012). The relationship between affective and continuance organizational commitment. Journal of Asian Business Strategy, 2(5), 89-94.

Malhotra, Y., \& Galletta, D. (2003). Role of commitment and motivations in knowledge management systems implementation: Theory, conceptualization, and measurement of antecedents of success. Proceedings of the 36th Hawaii International Conference on System Sciences.

Masa'deh, R. (2012). The impact of Management Information Systems (MIS) on Quality Assurance (QA): A case study in Jordan. International Journal of Information, Business and Management, 4(2), 93-110.

Masa'deh, R. (2013). The impact of information technology infrastructure flexibility on firm performance: An empirical study of Jordanian public shareholding firms. Jordan Journal of Business Administration, 9(1), 204-224.

Masa'deh, R., Gharaibeh, A., Maqableh, M., \& Karajeh, H. (2013). An empirical study of antecedents and outcomes of knowledge sharing capability in Jordanian telecommunication firms: A structural equation modeling approach. Life Science Journal, 10(4), 2284-2296.

Masa'deh, R., \& Shannak, R. (2012). Intermediary effects of knowledge management strategy and learning orientation on strategic alignment and firm performance. Research Journal of International Studies, 24, $112-128$.

Masa'deh, R., Shannak, R., \& Maqableh, M. (2013). A structural equation modeling approach for determining antecedents and outcomes of students' attitude toward mobile commerce adoption. Life Science Journal, 10(4), 2321-2333.

Mathieu, J. E., \& Zajac, D. M. (1990). A review and meta-analysis of the antecedents, correlates, and consequences of organizational commitment. Psychological Bulletin, 108, 171-194. http://dx.doi.org/10.1037/0033-2909.108.2.171

Mess, H. (2004). HRM best practice. Otago Management Graduate Review, 2, 25-37.

Meyer, J., Becker, T., \& Van Dick, R. (2006). Social identities and commitments at work: Toward an integrative model. Journal of Organizational Behavior, 27, 665-683. http://dx.doi.org/10.1002/job.383

Michailova, S., \& Gupta, A. (2005). Knowledge sharing in consulting companies: Opportunities and limitations of knowledge codification. Journal of Information \& Knowledge Management, 4(3), 201-212. http://dx.doi.org/10.1142/S0219649205001171

Morrissey, S. (2005). The design and implementation of effective knowledge management systems. MBA, Mack Center for Technological Innovation at the Wharton School.

Newkirk, H., \& Lederer, A. (2006). The effectiveness of strategic information systems planning under environmental uncertainty. Information \& Management, 43, 481-501. http://dx.doi.org/10.1016/j.im.2005.12.001

Newman, A., \& Sheikh, A. Z. (2012). Organizational rewards and employee commitment: A Chinese study. 
Journal of Managerial Psychology, 27(1), 71-89. http://dx.doi.org/10.1108/02683941211193866

Neyestani, M., Piran, M., Nasabi, N., Nosrati, K., \& Maidanipour, K. (2013). The necessity of organizational commitment for knowledge sharing case study: Shiraz university of medical sciences. Journal of Sociological Research, 4(1), 162-171. http://dx.doi.org/10.5296/jsr.v4i1.2921

Obeidat, B., Shannak, R., Masa'deh, R., \& Al-Jarrah, I. (2012). Toward better understanding for Arabian culture: Implications based on Hofstede's cultural model. European Journal of Social Sciences, 28(4), 512-522.

O'Leary, B., Lou Lindholm, M., Whitford, R., \& Freeman, S. (2002). Selecting the best and the brightest: Leveraging human capital. Human Resource Management, 41(3), 325-340. http://dx.doi.org/10.1002/hrm.10044

Oltra, V. (2005). Knowledge management effectiveness factors: The role of HRM. Journal of Knowledge Management, 9(4), 70-86. http://dx.doi.org/10.1108/13673270510610341

Ortega-Parra, A., \& Sastre-Castillo, M. A. (2013). Impact of perceived corporate culture on organizational commitment. Management Decision, 51(5), 1071-1083. http://dx.doi.org/10.1108/MD-08-2012-0599

Othman, A. E. A. (2009). Strategic integration of human resource management practices: Perspectives of two major Japanese electrical and electronics companies in Malaysia. Cross Cultural Management: An International Journal, 16(2), 197-214. http://dx.doi.org/10.1108/13527600910953937

Parker, H. (2012). Knowledge acquisition and leakage in inter-firm relationships involving new technology-based firms. Management Decision, 50(9), 1618-1633. http://dx.doi.org/10.1108/00251741211266714

Pinho, I., Rego, A., \& Cunha, M. P. (2012). Improving knowledge management processes: A hybrid positive $\begin{array}{llll}\text { approach. Journal of Knowledge } & \text { Management, }\end{array}$ http://dx.doi.org/10.1108/13673271211218834

Powell, T. H., \& Ambrosini, V. (2012). A pluralistic approach to knowledge management practices: evidence from consultancy companies. Long Range Planning, 45(2-3), 209-226. http://dx.doi.org/10.1016/j.lrp.2012.02.005

Qaisar, M. U., Rehman, M. S., \& Suffyan, M. (2012). Exploring effects of organizational commitment on employee performance: Implications for human resource strategy. Interdisciplinary Journal of Contemporary Research in Business, 3(11), 248-255.

Rašula, J., Vukšić, V. B., \& Štemberger, M. I. (2012). The impact of knowledge management on organizational performance. Economic and Business Review, 14(2), 147-168.

Riveros, A. M., \& Tsai, T. S. T. (2011). Career commitment and organizational commitment in for-profit and non-profit sectors. International Journal of Emerging Science, 1(3), 324-340.

Rocha, F., Cardoso, L., \& Tordera, N. (2008). The importance of organizational commitment to knowledge management. Comportamento Organizacional Egesta, 14(2), 211-232.

Rudge, A. (2011). Birmingham city council links increased contribution and outcomes to reward and recognition. Human Resource Management International Digest, $19(5), \quad 6-8$. http://dx.doi.org/10.1108/09670731111153258

Sanders, K., Dorenbosch, L., \& De Reuver, R. (2008). The impact of individual and shared employee perceptions of HRM on affective commitment: Considering climate strength. Personnel Review, 37(4), 412-425. http://dx.doi.org/10.1108/00483480810877589

Savaneviciene, A., \& Stankeviciute, Z. (2011). Human resource management practices linkages with organizational commitment and job satisfaction. Economics and Management, 16, 921-928.

Sayğan, F. N. (2011). Relationship between affective commitment and organizational silence: A conceptual discussion. International Journal of Social Sciences and Humanity Studies, 3(2), 219-227.

Saxon, N. L. (2012). Understanding organizational commitment and satisfaction of TACOM life cycle management command acquisition, technology, and logistics associates. Unpublished Master Thesis, Lawrence Technological University.

Sekaran, U. (2003). Research methods for business (4th ed.). Hoboken, NJ: John Wiley \& Sons.

Shahnawaz, M. G., \& Juyal, R. C. (2006). Human resource management practices and organizational commitment in different organizations. Journal of the Indian Academy of Applied Psychology, 32(3), 
$171-178$.

Shannak, R., Masa'deh, R., \& Akour, M. (2012). Knowledge management strategy building: Literature review. European Scientific Journal, 8(15), 143-168.

Shannak, R., Masa'deh, R., Obeidat, B., \& Almajali, D. (2010). Information technology investments: A literature review. Proceedings of the 14th IBIMA Conference on Global Business Transformation through Innovation and Knowledge Management: An Academic Perspective, Istanbul-Turkey.

Shannak, R., Masa'deh, R., Al-Zu'bi, Z., Obeidat, B., Alshurideh, M., \& Altamony, H. (2012). A theoretical perspective on the relationship between knowledge management systems, customer knowledge management, and firm competitive advantage. European Journal of Social Sciences, 32(4), 520-532.

Shannak, R., Obeidat, B., \& Masa'deh, R. (2012). Culture and the implementation process of strategic decisions in Jordan. Journal of Management Research, 4(4), 257-281. http://dx.doi.org/10.5296/jmr.v4i4.2160

Sripirabaa, B., \& Krishnaveni, R. (2009). Performance management systems in an Indian manufacturing sector (Partnering, monetary incentives and the alignment of organizational goals). Management Research News, 32(10), 942-952. http://dx.doi.org/10.1108/01409170910994150

Škerlavaj, M., Song, J. H., \& Lee, Y. (2010). Organizational learning culture, innovative culture and innovations in South Korean firms. Expert Systems with Applications, 37, 6390-6403. http://dx.doi.org/10.5296/jmr.v4i4.2160

Suma, S., \& Lesha, J. (2013). Job satisfaction and organizational commitment: The case of Shkodra municipality. European Scientific Journal, 9(17), 41-52.

Tan, C. L., \& Nasurdin, A. M. (2011). Human resource management practices and organizational innovation: Assessing the mediating role of knowledge management effectiveness. Electronic Journal of Knowledge Management, 9(2), 155-167.

Thompson, M., \& Heron, P. (2005). The difference a manager can make: Organizational justice and knowledge worker commitment. International Journal of Human Resource Management, 16(3), 383-404. http://dx.doi.org/10.1080/0958519042000339561

Tiwari, P., \& Saxena, K. (2012). Human resource management practices: A comprehensive review. Pakistan Business Review, 669-705.

Ubeda-Garcia, M., Marco-Lajara, B., Sabater-Sempere, V., \& Garcia-Lillo, F. (2013). Does training influence organisational performance? Analysis of the Spanish hotel sector. European Journal of Training and Development, 37(4), 380-413. http://dx.doi.org/10.1108/03090591311319780

Ul Quresh, F., \& Uppatumwichian, W. (2008). Information technology and organizational learning. Unpublished Master Thesis, Malardalen University.

Vanhala, S., \& Stavrou, E. (2013). Human resource management practices and the HRM-performance link in public and private sector organizations in three Western societal clusters. Baltic Journal of Management, 8(4), 416-437. http://dx.doi.org/10.1108/BJM-12-2012-0115

Vlachos, I. P. (2009). The effects of human resource practices on firm growth. International Journal of Business Science and Applied Management, 4(2), 18-34.

Vrîncianu, M., Anica-Popa, L., \& Anica-Popa, I. (2009). Organizational memory: An approach from knowledge management and quality management of organizational learning. Amfiteatru Economic, 11(26), 473-481.

Wheelen, T. L., \& Hunger, J. D. (2013). Strategic management and business policy: Toward global sustainability. New Jersey: Pearson.

Yap, J. E., Bove, L. L., \& Beverland, M. B. (2009). Exploring the effects of different reward programs on in-role and extra-role performance of retail sales associates. Qualitative Market Research: An International Journal, 12(3), 279-294. http://dx.doi.org/10.1108/13522750910963809

Yew, L. T. (2013, July 8). The influence of Human Resources Management (HRM) practices on organizational commitment and turnover intention of academics in Malaysia: The organizational support perspective. Paper presented at the International Conference of Business and Information, Bali, Indonesia.

Zaitouni, M., Sawalha, N. N., \& El, S. A. (2011). The impact of human resource management practices on organizational commitment in the banking sector in Kuwait. International Journal of Business and Management, 6(6), 108-123. http://dx.doi.org/10.5539/ijbm.v6n6p108 
Zhou, Y., Zhang, Y., \& Montoro-Sa'nchez, A. (2011). Utilitarianism or romanticism: The effect of rewards on employees' innovative behaviour. International Journal of Manpower, 32(1), 81-98. http://dx.doi.org/10.1108/01437721111121242

\section{Copyrights}

Copyright for this article is retained by the author(s), with first publication rights granted to the journal.

This is an open-access article distributed under the terms and conditions of the Creative Commons Attribution license (http://creativecommons.org/licenses/by/3.0/). 